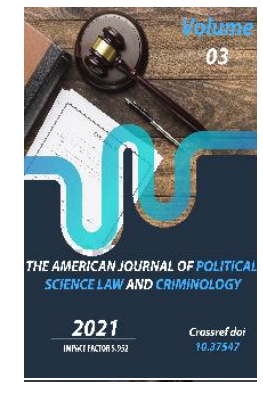

Journal Website: http://usajournalshub.c om/index,php/tajpslc

Copyright: Original content from this work may be used under the terms of the creative commons attributes 4.0 licence.

\section{Issues Of Ensuring Tolerance In The Activities Of Religious Denominations And International Organizations (Political- Legal Analysis)}

\author{
Shokhijakhon Eshpulotovich Toshpulotov
}

Lecturer, Tashkent State University Of Law, Uzbekistan

\title{
ABSTRACT
}

The article reveals with the information on the principles of tolerance in international relations and its brief history in humanity, as well as on issues of ensuring religious tolerance in the activities of the religious denominations and international organizations. There is also given the information about the principles of international law and interreligious relations and the rights of the states and individuals who are belonging to certain religions.

\section{KEYWORDS}

Freedom of religion and freedom of conscience, inter-religious inter-confessional tolerance, confessions, norms and principles of international law and politics on tolerance.

\section{INTRODUCTION}

The contradictory process of creating a global community, the strengthening ofhuman capabilities for creation and destruction, and the rapid change in the geopolitical and 
demographic situation in the world have recently brought to the fore the problem of theclash of religious values on a global scale.

Global changes in the socio-political picture of the world also contribute to this. According to widespread opinion among historians and political scientists is that the twenty-first century will be an era of ethnic and ethnoreligious conflict. The global factors which shaped world events in the second half of the last century have become a thing of the past. It seems as if humanity, having got rid of ideologically-motivated conflicts, has moved on to the solution of more significant and urgent problems...

Nationalism and religion ... proved to be an incomparably stronger motivation than class enmity and the desire for social equality."In the context of the growing conflict in the modern world of world religions as factors of national and cultural identity, directed against the tendency to the blurring of cultural and political differences between countries and people.

The confrontation of world religions, primarily Christianity and Islam, comes to the fore, two great world religions that embody an ethical, cultural, and political choice between different strategies for the future development of humanity. At the same time, political cynicism, the selfish interests of the "great powers", the predominance of material interests over spiritual ones, mass culture andmany other factors have been rapidly destroying ethical truths for centuries preserved and supported by world religions.

Many researchers consider to be decisive for the fate of the world, it is necessary to consider the current state of relations between the state and the church,which is important for political liberalism.

As already noted, liberalism emerged on the basis of the religious fragmentation of Europe after the Reformation and the religious wars of the XVI-XVII centuries, which raised the question of how society can coexist various interpretations of Christianity. Tolerance was suggested as the best answer to this question. D. Rawls put it this way: "Historically political liberalism(liberalism more generally) has its the origin of the reformation and its consequences, which led to a long discussions on religious tolerance XVI-XVII centuries." D. Rawls considered his version of political liberalism as a continuation of this tradition and believed that she "complements and extends that line of thought, which had started three centuries ago.

It resulted in a growing recognition of the principle of tolerance and led to a nondenominational state and freedom of conscience."

Recently, however, some authors have expressed doubts about the adequacy of the assessment of liberalism as a way to resolve religious conflict. For example, P. Manen believes that liberalism was motivated not so much by the desire to resolve a religious conflict, but by the desire to get rid of the church as an institution. In fact, he believes, it was an attempt to solve political issues outside the categories good and evil, since their use is the responsibility of the church.

In other words, liberalism arose not so much from the need to find a solution to a religious conflict, but rather from its own ideological preferences, which contradicted the institutional religion. His arguments are 
developed by W. Kavanaugh. He believes that the so-called religious wars"were actually the birthplace of the state since they were largely fought for the sake of expanding states that emerged from the wreckage of the medieval ecclesiastical order.

They were motivated by a desire for power, not by theological or ecclesiastical beliefs. From the point of view of classical liberalism, the picture isas follows: a neutral liberal state has stopped the bloodshed and wars that occurred due to the irreconcilable desire of religion to proclaim the absolute truth. However, the history of the XIX and XX centuries shows not a decrease, but an increase in bloodshed and wars in the world. The state was supposed to keep the peace, helping to overcome the violence generated by religion. But then the blood was shed not in the name of religion, but in the name of democracy and freedom. From Kavanaugh's point of view, the call of liberalism was nothing more than a call to serve the state, not the church. [1-5]

Indeed, the solution once proposed by J.J. Rousseau and D. Locke, was based on a certain ideology which had considerable theological and ecclesiastical implications. They saw the danger of Christianity in its potential ability to limit the loyalties of citizens to the political system in the name of loyalties to the ecclesiastical system. Tolerance could only extend to those who agree to limit their commitment to Christianity to a level which does not interfere with their primary allegiance to the state. Tolerance therefore did not extended to Catholics who remained convinced of the universal nature Church and loyalty to the papacy. From the point of view of some scholars, tolerance was realizable in the US because under Protestantism's influence such universalist denominations such as Catholicism and Judaism have largely lost face and accepted the general principle thatcommunity of faith unites around a particular, private belief system.

\section{METHODS}

Freedom of religion and belief refers to basic human rights, which expressed in the fundamental international documents:

- The Universal Declaration of Human Rights (1948),

- The International Treaty on Civil and Political rights(1966

- The Declaration on the Elimination of All Forms of Religious Intolerance and discrimination (1981)

- The Declaration on the Rights of Persons Belonging to National, Ethnic, Religious and linguistic minorities (1992).

In recognition of every citizen's constitutional rights to spread their religious beliefs, the relationship between believers and the heads of various religious associations, as well as the relationship between religious groups and the government should be based on the following principles:

$\checkmark$ Freedom of conscience, expression and dissemination of religious beliefs and the desire to convince others of the truth of their own beliefs is an essential natural right of every human being. At the same time, everyone has the right to choose or change their religious beliefs.without compulsion and in accordance with one's conscience;

$\checkmark$ Any form of compulsion to change or preserve one's religion must be condemned and rejected; 
$\checkmark$ Religious associations, guided by the principle of socialresponsibility, should build relations with each other through dialogue, not confrontation, expressing their opinions with humility, sincerity and respect for other opinions;

$\checkmark$ The dissemination of religious beliefs by believers should be accompanied by an impartial attitude towards other religious organizations by objectively comparing one's beliefs with other religious groups;

$\checkmark$ The dissemination of religious beliefs should be based on the protection of the rights of not only the majority, but also the minority, in accordance with international legal norms that condemn all forms of discrimination and intolerance;

$\checkmark$ When conducting social, charitable, cultural and educational activities, it should be avoided to link them with such a dissemination of beliefs that presuppose financial or material benefits for people in difficult social conditions to encourage them to adhere to certain religious beliefs or change them;

$\checkmark$ No one should make deliberate or unintentional statements about other religions, or ridicule the beliefs and customs of others. It is necessary to rely on objective information about other religions in order to avoid sweeping prejudices;

$\checkmark$ The freedom to disseminate religious views and beliefs is not absolute. It is subject to the legal restrictions required to maintain public order, protect public health, the integrity of family ties, and the legitimate rights of others in case of conflicts between religious organizations,

$\checkmark$ In connection with the dissemination of religious views and beliefs, every opportunity for reconciliation should be sought. If it is necessary for a state to intervene in these conflicts, it is necessary to proceed from the priority of their peaceful resolution, but in all cases strictly follow the laws of the State and the norms of international law.

\section{RESULTS AND DISCUSSIONS}

However,since society is built on the principles of political liberalism, its main goal is, ultimately, to develop a position that can influence political decisions. Communication should take place between public organizations, between people who are members of them and between people who are not members of any organizations, and its content should relate not only to political issues, but also to any life problems. Communication should take into account the pluralistic reality at different levels and help to develop an ethos interactions between people. To do this, communication between different identities must take place not only in words, but also in practice. This rethinking of communication is particularly relevant in the light of recent concerns about the disappearance of the public sphere from modern liberal politics and the decline of civil society in Western countries.

Communication should not be an attempt to achieve consensus byleveling fundamental differences. Some modern Westernpolitical philosophers believe that the use of the concept of "dialogue" should be avoided altogether, which, as a rule, is based on the assumption that the differences that arise in it should be subordinated to higher universal categories. On the contrary, inthe type of communication that is built on communication between people, they get the opportunity to learn more about each other's lives, without 
giving up on differences. The purpose of this communication is not limited to discussing those issues on which the participants agree with each other in advance and which they are able to express and understand in a rational form. It cannot be assumed that the only way to achieve stability and justice in a pluralistic political society is to develop a language and arguments with which everyone agrees.

It is necessary to learn to understand people precisely in their differences and particulars. The belief that religion entails a greater tolerance than many forms of secular ideologies are a reflection of cultural myth a liberal society. In fact, all theories, philosophical systems, and ideologies involve conflicting views that can potentially be intolerant. In addition, some researchers believe that religious discourse provides a positive vision that manifests itself only within the framework of religious language, and that the requirement to use "neutral" language inevitably leads to a weakening of religious beliefs.

\section{CONCLUSION}

The modern era is evidence of the active growth of the role of the religious factor in the world. At the same time, there are exceptions: in Western and Eastern Europe. Central Europe is indeed experiencing a significant decline in religion, which has become an important component of European cultural identity. The other exception is the sociological one, and consists in the presence of such a relatively small but influential group as the international intelligentsia, for which secularization has become not only a fact, but an ideological commitment, according toat least for some of its members.
However, today's world is more characterized not by secularization, but by pluralism - the peaceful coexistence of different racial,ethnic or religious groups in one society. Modernity undermines the traditional homogeneity of society, because insiders and outsiders constantly face each other physically(thanks tourbanization and travel) or "virtually" (thanks to mass literacy and mass media and communications). Pluralism, accelerated, expanded and strengthened by globalization, it has become an integral part of public life and people's consciousness. At the institutional level, pluralism means that recognized religions can no longer take forgranted that a certain group of the population passively recognizes their authority. If religious freedom is guaranteed, which is a typical situation under a liberal democratic system, religious institutions can not rely on state assistance to replenish their flock. [6-9]

People must be persuaded to accept this authority, which gives rise to a kind of religious market. Even if one religious tradition still counts a large part of the population as its nominal adherents, anyone can voluntarily withdraw from the organization representing that tradition(such as, for example, in the predominantly Catholic countries of Europe). At the level of individual consciousness, this means that religious certainty is becoming increasingly rare. Choosing a religion can be a matter of choice a passionate commitment or, more often, a consumer choice (which perfectly conveys the American expression "religious preference"). In any case, a person is left to himself in understanding and forming his own opinion about his native religious tradition. 


\section{REFERENCES}

1. Criado, H., Herreros, F., Miller, L., \& Ubeda, P. (2014). Ethnicity and Trust: A Multifactorial Experiment. Political Studies.

2. Grim, B. J., \& Wike, R. (2010). CrossValidating Measures of Global Religious Intolerance: Comparing Coded State Department Reports with Survey Data and Expert Opinion. Politics and Religion, 3(01), 102-129.

3. Humphreys, M. (2003). Economics and violent conflict. Program on Humanitarian Policy and Conflict Research, Harvard University, February.

4. Inglehart, R. (1997). Modernization and postmodernization: Cultural, economic, and political change in 43 societies (Vol. 19). Princeton, NJ: Princeton University Press.

5. Norris, P., \& Inglehart, R. (2011). Sacred and secular: Religion and politics worldwide. Cambridge University Press.

6. Тошпулотов Ш. Э. THE ROLE OF INTERRELIGIOUS TOLERANCE IN ENSURING SOCIO-POLITICAL STABILITY: UZBEKISTAN AND FOREIGN EXPERIENCE //Ижтимоий фанлар. 2020. - T. 5. - №. 3. Available at: https://scholar.google.com/scholar?oi= bibs\&cluster $=15784578658660743672$ \&btnl=1\&hl=ru

7. Eshpulotovich T. S., Turayevich S. U. International Political Mechanisms For Ensuring Religious Tolerance And The Importance of Its Teaching In Educational Institutions //European Journal of Molecular \& Clinical Medicine. - 2020. - T. 7. - №. 3. - C.
5265-5268. Available at: https://scholar.google.com/scholar?oi= bibs\&cluster $=15784578658660743672$ \&btnl=1\&hl=ru

8. Eshpulotovich T. S. THE REFLECTION OF THE PHENOMENON OF FREEDOM OF CONSCIENCE AND THE PRINCIPLE OF INTERRELIGIOUS TOLERANCE IN THE LEGISLATION OF THE INTERNATIONAL COMMUNITY AND UZBEKISTAN //International Engineering Journal For Research \& Development. - 2020. - T. 5. - №. ICIPPS. - C. 5-5...Available at: // https://scholar.google.com/scholar?oi= bibs\&cluster $=3195783177761830836 \& b$ tnl=1\&hl=ru

9. Toshpulotov Sh.E.The role of foreign experience in ensuring religious tolerance: world and national approach. Вестник науки и образования № 25(103), 2020, С. http://scientificjournal.ru/images/PDF/2 020/103/the-role-of-foreignexperi.pdf//

10. Тошпулотов Шохижахон Отношение к религиозной терпимости в международной политике и законодательстве Узбекистана // Review of law sciences. 2020. №Спецвыпуск. $\quad$ URL: https://cyberleninka.ru/article/n/otnos henie-k-religioznoy-terpimosti-vmezhdunarodnoy-politike-izakonodatelstve-uzbekistana (дата обращения: 11.03.2021). Available at: https://scholar.google.com/scholar?oi= bibs\&cluster $=1468611173384390572 \& b$ tnl $=1 \& h l=r u$ 